\title{
Gone but not Forgotten: Female Pioneers in Black Entrepreneurship
}

\author{
Toni Sims-Muhammad* \\ Associate Professor, Social Sciences and African American Studies, Allen University, Columbia
}

Submission: October 17, 2019; Published: October 22, 2019

*Corresponding author: Catherine Adams, Associate Professor, Africana Studies, Claflin University, Orangeburg, SC, Columbia

\begin{abstract}
This paper examines the following research questions: 1) Who were historical black female entrepreneurs - develop identifiers/ characteristics for a profile 2) What types of businesses did they own, and what factors may have led to their entrepreneurship; and 3) What impact might age, region, educational status, marital status, and family size have had in their business pursuits? The paper employs storytelling (narrative) content analysis on the lives of four historical black female entrepreneurs: Clara Brown; Christina Bannister; Sara E. Goode and Maggie Lena Walker. Analysis reveals common challenges, aptitude and agency for forging independence and opportunities in $19^{\text {th }}$ century American society.
\end{abstract}

Keywords: African American Female Entrepreneurs; Black Female Pioneers; Black Entrepreneurs

\section{Introduction}

What can we tell today's black female entrepreneurs about the struggles and hard work of black female entrepreneurs who predate them? Many, often untold stories of success. Black female entrepreneurs are one of the most resourceful groups to emerge during 19th century America. For the purposes of this study, I focused on four historical black female entrepreneurs. I sought to explore three things:

a. Who were historical black female entrepreneurs and how to develop identifiers/characteristics for a profile,

b. What types of businesses did they own, and what were the factors that may have led to their entrepreneurship, and

c. What impact might age, region, educational status, marital status, and family size have had on their business pursuits?

\section{From Enslavement, through Jim Crow, to Agency}

For this study, I performed a narrative/content analysis on Clara Brown, Christina Bannister, Sara E. Goode, and Maggie Lena Walker, primarily based on recorded biographic data/ narratives about their lives, work, and families. These four were chosen because they remain relatively unknown for their contributions to American society and because their lives reflect the earliest known characteristic of entrepreneurship exhibited by African American women [1-3]. A specific focus on this study was to identify critical or common themes between their lives and entrepreneurship. The descriptors for categorizing items into these themes were actions, reactions, and interactions reflected in their histories or, rather, herstories-a major source of information and data about the lives of American black female entrepreneurs. Social scientists note that storytelling is a valid research method [4-6] to perform data analysis that provides engaging, coherent and memorable insights and information. It also allows the research the opportunity to clean data, categorize data and sometimes to perform bivariate or even multivariate analysis. Additionally, narrative/content analysis is a flexible design research method with a broad range of applications, associated processes and variations. While there are no universal standards for implementation, there are a variety of documented procedures for using storytelling for different purposes within a design research project [7].

\section{Findings}

To the first research question:

a. Who were historical black female entrepreneurs and what identifiers and characteristics describe her? Narratives/storytelling reflect that Brown, Bannister, Goode, and Walker, all born before the end of the Civil War, can be profiled using a historical time frame of activities in the nineteenth and early twentieth century; industries of entrepreneurship, which include: owners of laundering businesses, beauty salons, furniture stores, banks, stores, and newspapers; geographic location/region-from Boston down to Virginia, and over to Chicago and Colorado; and a 
moniker unique to each entrepreneur, including the Gold Rush, patents earned, financier success, and success during the Great Depression. To the second research question:

b. What types of businesses they owned, as well as factors that may have led to their entrepreneurship narratives/ storytelling reflect the following common factors regarding enslavement, family loss, and economic survival? To the third research question:

c. What impact might age, region, educational status, marital status and family size played in their business pursuits? The narratives/storytelling reveal a range of ageslate teenage to early 50s-regarding study and practice in industry, a regional reach from the east, to the northeast, and Midwest, without formal education as a prerequisite for these married (at least once) women with three of the four experiencing motherhood. Additionally, this examination was supported by the ways that the black female entrepreneurs

i. Handled challenges, rejection and/or loss;

ii. Demonstrated wit, attitude and will to push or pull forward and

iii. Their creativity and/or uniqueness as a forerunner in a particular market.

\section{Conclusion}

Clara Brown, Christina Bannister, Sara E. Goode, and Maggie Lena Walker were entrepreneurs who persevered not despite of but rather because of racism and sexism; they can serve as torch bearers and standard markers for successful entrepreneurship. This paper provides a sociohistorical analysis of their lives and specifically their abilities to

1) handle hostility, rejection and/or loss;

2) demonstrate wit, attitude and will to push or pull forward

3) creativity and/or uniqueness as pioneers in industry and role models for today's black female entrepreneurs.

\section{References}

1. Sullivan OR, Haskins J (2002) African American women scientists and inventors. Wiley, New York, USA.

2. Walk-Morris T (2018) Madame Christiana Carteaux Bannister is the Black Beauty Hero You Haven't Heard of. BUSTLE Feb 92018.

3. Wiltz T (2014) Great African-American Entrepreneurs Who Made History, 2/10/14 The ROOT.

4. Christensen J (2012) Telling stories: Exploring research storytelling as a meaningful approach to knowledge mobilization with Indigenous research collaborators and diverse audiences in community-based participatory research. The Canadian Geographer / Le Géographe canadien 56: 231-242.

5. Werk N (December 2017) The power of storytelling in research.

6. Woodside, AG (2016) Storytelling Theory and Research (edn.) Case Study Research p. 41-83.

7. Creswell JW, Poth CN (2017) Qualitative Inquiry and Research Design: Choosing Among Five Approaches. Sage Publishers. ( $4^{\text {th }}$ edn), Los Angeles, USA.

\section{Your next submission with Juniper Publishers will reach you the below assets}

- Quality Editorial service

- Swift Peer Review

- Reprints availability

- E-prints Service

- Manuscript Podcast for convenient understanding

- Global attainment for your research

- Manuscript accessibility in different formats

( Pdf, E-pub, Full Text, Audio)

- Unceasing customer service

Track the below URL for one-step submission https://juniperpublishers.com/online-submission.php 